\title{
Consumer Perception and Satisfaction towards Online Shopping
}

\author{
Wu Baofu ${ }^{1}$, Ch. Sai Ramnadh ${ }^{2}$ and Hye-jin Kim ${ }^{3}$ \\ ${ }^{1}$ Hangzhou Dianzi University, No.1158\# Baiyang Second Street, Hangzhou Economic \\ Development Zone, Hangzhou City, Zhejiang Province, China \\ ${ }^{2}$ Department of Management Studies \\ Vignan's University, Vadlamudi, Guntur, Andhra Pradesh, Vignan \\ ${ }^{3}$ Business Administration Research Institute, Sungshin W. University, 2, Bomun-ro \\ 34da-gil, Seongbuk-gu, Seoul, Korea \\ ${ }^{1}$ Wubf12345@sina.com, ${ }^{3}$ hyejinaa@daum.net
}

\begin{abstract}
The growing use of the web in India provides a developing prospect for online shopping. If E-marketers understand the factors affecting online Indian behavior, and also the relationships between these factors and also the type of online buyers, then they'll additionally develop their selling methods to convert potential customers into active ones, whereas retaining existing online customers. This project could be a part of the study and focuses on factors that online Indian buyers keep in mind while shopping online. This analysis found that info, perceived utility, easy use; perceived enjoyment, and security/privacy are the 5 dominant factors that influence shopper perceptions of online getting. Shopper behavior is alleged to be associated with applied discipline as some choices are considerably full of their behavior or expected actions. The two views that seek application of its knowledge are small and societal perspectives. The web is changing the way shoppers look and buy products and services and has rapidly evolved into global development. Many firms have started using the web to cut marketing costs, thereby reducing the value of their product and services to remain ahead in extremely competitive markets. Firms additionally use the net to convey, communicate and distribute info, to sell the product, to take feedback, and also to conduct satisfaction surveys with customers.
\end{abstract}

Keywords: E-market, Online shopping, Products, Customers

\section{Introduction}

\subsection{Introduction to industry}

- Online shopping in India: The birth and growth of the Internet have been the biggest event of the century most corporations are using the Internet to represent their product range and services so it's accessible to the world market and to achieve out to a larger vary of their audience. Computers and also the net has fully changed the method one handles daily transactions; online shopping is one in all of them. the net has led to sweeping changes in the buying habits of individuals. in the comfort of one's home, workplace or cyber restaurant, or anyplace across the world, one will go online and buy just about anything from apparel, books, music, and jewelry to digital

Article history:

Received (January 6, 2014), Review Result (February 15, 2014), Accepted (April 26, 2014) 
cameras, mobile phones, MP3 players, video games, movie tickets, rail and air tickets. Ease, simplicity, convenience, and security are the key factors turning the users to shop online [1].

- Factors that boost online shopping in India: Few of the numerous features that get covered under the essential factors that are required o boost online shopping in India include Rapid growth of cybercafés across India, Access to Information, The increase in the number of computer users, Reach to net services through broadband and also Middle-class population with spending power is growing. There are about 200 million middle-class population good spending powers. These people have very little time to spend shopping. Many of them have started to depend on the internet to satisfy their shopping desires.

- Few facts about online shopping: Indian online matrimonial sector is worth around $\$ 230$ million, Worldwide E-commerce is only growing at the rate of $28 \%$, since India is a younger market, the growth of e-commerce is expected at $51 \%$ in the coming years. In line with global trends finally, India has also started shopping online these days [7]. As per the study by IAMAI online shopping in India has risen from \$11million in 1999-2000 to \$522 million in 2007 and it is expected to rise above $\$ 700$ million by end-March 2013 all these are a few important factors that play a violent role in online shopping.

\subsection{Introduction to problem}

\subsubsection{Change attitude toward online shopping}

Awareness among the consumers is spread through the internet. The number of internet users is increasing day by day which attracts people who have an option to buy online. It was never thought that Indians would go in for e-shopping in such a big way. Ticketing, travel bookings, and even books and movies seem fine to buy online. In India, there are some segments of people who have not yet tried purchasing over the internet [3].

\subsubsection{Reasons for preferences of internet shopping [5]}

1. Convenience: Online stores are sometimes available twenty-four hours each day, and lots of customers have web access both at work and at home. Other establishments like web cafes and colleges give access additionally.

2. Information and reviews: Online stores must describe products for sale with text, photos, and multimedia files. Some stores even permit customers to comment or rate their things. Reviews and now blogs provide customers the choice of searching for cheaper organized purchases from all over the globe without having to depend on native retailers.

3. The home delivery concept: In any case, home delivery is a concept that Indians are familiar with and love. Earlier it was a choice between sweating it out in small crowded markets or asking a friendly neighborhood (grocer) to deliver groceries home and this system is still thriving.

4. Increase in Internet users: Increasing penetration of Internet connectivity and PCs has led to an increase in Internet users across India. These segments are the users of advanced applications and technologies online and are most likely to be heavy ECommerce users. 
5. Increase in the number of buyers and sellers: The success of a marketplace depends on the presence of a large number of buyers and a large number of sellers. In addition to online buyers, many offline stores have begun to sell their products in the online marketplace. The greater the number of sellers and buyers, the faster the market grows.

\section{Online shopping sites}

Many online e-shopping websites provide many convenient and easy methods in shopping to users, these are namely Amazon, flip kart, snap deal, Paytm, eBay, jabong, myntra, Shopclues, etc the major similarities among these sites are namely [2],[6]:

1. Accessories: Mobiles \& Accessories, Men's \& Women's Apparel, Watches, Bags \& Accessories, Electronics \& Cameras, Computers \& Peripherals, Perfumes, Beauty \& Health, Jewelry, Books \& Movies, Footwear, Home, Kitchen \& Appliances, Infants, Kids \& Toys, Sports \& Hobbies, Travel Packages, Adventure \& Entertainment.

2. Terms of Sale, Website Terms of Use, Privacy Policy: This User Agreement, which is intended to be a legally binding contract between you and us, contains the following:

$>$ Terms of Sale: this governs your purchase and use of the coupons/vouchers,

$>$ Website Terms of Use: this governs the access and use of the Website,

$>$ Privacy Policy: this governs the use of the personal information we collect.

3. Return policy: There can be certain circumstances beyond our control where you may receive a broken / defective product or a product that's not similar to your original order. We are going to replace the product to your satisfaction at no additional value. In such circumstances, we might request you to get in touch with our Customer Service. The return method of the product is also restricted betting on the nature and category of the product [8].

\section{Conditions for return}

$>$ Please inform us of receipt of a broken / Defective product within forty-eight hours of delivery. If you're unable to try and do this within forty-eight hours, there shall be no liability of Snapdeal.com to replace the order Products/Items ought to be UNUSED.

$>$ Snapdeal.com can organize pickup of the damaged/defective product through its provision partner. In the event of Snapdeal.com not having the ability to urge the pickup arranged, you may need to send the merchandise using one of the reputed couriers in their area. Courier freight charges reimbursement are as sd cash if any and up to a maximum as outlined by our provision team.

$>$ It is suggested that the return packets ought to be powerfully and adequately packaged so there's no additional harm to the product in transit. The returned goods are subject to verification and checks from the Snapdeal.com team to judge the legitimacy of the complaint.

5. Refunds: Refunds are going to be processed based on the mode of payment of the order

1. Orders paid online are refunded at intervals of 7-21 operating days

2. For COD payments, we will send a refund cheque.

\section{Bulk order cancellation policy}

Snap deal reserves the right to cancel any orders that classify as 'Bulk Order' as per internal criteria [4].

$>$ Any SD cash or Promo Code used for placing the 'Bulk Order' will not be refunded as per our cancellation policy 
$>$ Some of the reasons that an order is classified as 'Bulk Order' are listed below

$>$ Where it is felt that the products ordered are not for self-consumption but a further sale

$>$ Multiple orders placed for the same product at the same address

$>$ Bulk quantity of the same product ordered

$>$ Invalid address given in order details

$>$ Any malpractice is used to place the order

\section{Problem statement}

During the research study, it was found that the customer-facing numerous problems in online shopping in India. Some problems are listed here:

$>$ Quality and right product: after getting the delivery of the product the customer may come to know that customer has purchased the wrong product. The size which the customer is not as per customer requirement or might have chosen the wrong size. If the customer replaces the product will have to pay the extra shipping charges.

$>$ Return policy: This is another factor that is important while shopping online. Sometimes the customers don't look and feel the product, there are chances to return while not satisfied with the delivered product. Hence, the company does not accept the return policy of the product.

$>$ Hidden charges: while doing online shopping check the final price, as the shipping charges may not be added to the product and the displayed price may differ.

$>$ Security: There are some "scam online stores" also, on those websites online shopping may not be safe, they may offer the products at low cost but might collect card payment details and personal details.

$>$ Delivery problem: Some websites inform the delivery time immediately after the purchase of the product, but not all. Sometimes the company does not deliver the product at the time.

\section{Literature review}

These days E-commerce may be a common word in Indian society and it's become an integral part of our everyday life. Websites are providing some goods and services. Real estate and services. Ramirez Nicolas (2010) states that "The Internet has changed many facets of our daily lives: the way we relate and communicate with one another, how we interact with a bank, read newspapers or watch television. This led Andrew Mason in 2008 to launch "The Point", an online community to obtain the best group deals. In the November of the same year, the famous "Group on" was incorporated. Currently, Group on is present in over 45 countries around the world since March 2010 and has received multi-million dollar bids from industry giants like Yahoo! and Google. All these benefits have triggered a rush among shoppers to shop for discount coupons and also the rate of user growth is rising continuously. Donald Rogan (2007) explains the relationship between shopper behavior and selling strategy. He states that strategy is regarding increasing the probability and frequency of buyer behavior. Requirements for succeeding in doing this are to know the customer and understand the consumer's needs and wants. The expectation-confirmation model (Oliver 1980), on the opposite hand, focuses on post-purchase behavior. It's a widely used model within the consumer behavior literature, particularly in explaining consumer satisfaction and repeat purchase. Satisfaction is that the central notion of this model and it's shaped by the gap between expectation and perceived performance (Oliver 1980). The expectation-confirmation 
theory suggests that if the perceived performance meets one's expectation, confirmation is made and customers are glad.

Customer online purchase intention: As per the idea of reasoned action, consumer behavior can be expected from its corresponding intentions (Ajzen and Fishbein, 1980). client online purchase intention is outlined as the construct that provides the strength of a customer's intention to buy online (Salisbury et al., 2001). To trigger online purchase intention among customers, internet retailers usually need to focus on these factors to enhance the chance of purchase by customers.

Online trust and customer online purchase intention: online trust may be a necessity when it comes to online shopping (McCole and Arnold Palmer, 2001). Due to the risky nature of shopping, trust and risk play vital roles in affecting online transactions (Pavlou, 2003). within the Indian context, the influence of online trust as of mediating result has been studied on client online purchase intention (Ganguly et al., 2009). Varied studies have concluded have ended that higher consumer online trust can end in higher customer online purchase intention (Verhagen et al., 2006; McKnight et al., 2002; Lim et al., 2006; Ling et al., 2010).

Prior online purchase expertise and customer online purchase intention: Future behavior is decided by previous experiences. online purchases are still thought of to be risky compared to offline retail purchases (Laroche et al., 2005). In an online shopping environment, prior online purchase experience leads to the reduction of uncertainties and eventually leads to an increase in the customer purchase intention (Shim and Drake, 1990). Online shoppers who have bought merchandise online are more open and inclined to shop online than others (Lee and Tan, 2003).

Shopping orientations and customer online purchase orientation: looking orientations are outlined as a general disposition toward the acts of searching (Brown et al., 2001). Swaminathan et al.(1999) declared that shopping orientation is one of the prime indicators of making online purchases. Seven shopping orientation varieties known by Gehrt et al. (2007)are recreation, novelty, impulse purchase, quality, brand, worth and convenience Of all the seven shopping orientations, impulse purchase orientation, quality orientation, and brand orientation were perceived as more important from the web retailer perspective and often investigated together (Ling et al., 2010).

- Impulse purchase orientation Impulse purchase behavior happens when a customer feels the urge to purchase something at the very instant without any more evaluation (Rook, 1987). According to Piron (1991), Impulse purchase behavior is an action done without any prior plan as a result of a stimulus.

- Brand orientation In internet transactions, customers use trusted corporate and brand names in place of product information while purchasing online (Ward and Lee, 2000). Jayawardhena et al.(2007) have established from their study that there's a major effect of brand orientation on customer online purchase intention.

- Quality orientation Bellenger and Korgaonkar (1980) found that one of all the items that recreational shoppers tend to need into thought is quality once selecting stores for shopping.

Demographic factors Though demographic variables are not extensively studied, males were found to shop online more than females (Li et al., 1999). After a detailed study, it was found that the profile of online shoppers tends to be male, well educated, between 21 and 30, and have a high internet usage. Hence in this research study, it was proposed to study the effect of gender, age, education, level of internet usage, credit card, and computer usage experience on customer online purchase experience. 


\section{Research design}

The purpose of the methodology is to design the research procedure. This includes the overall design, the sampling procedure, the data collection method, and the analysis procedure.

There are two types of researches, which according to their applicability, strength, weaknesses, and requirements used in selecting the proper type of research, their suitability must be seen to a specific problem two general types of researches are exploratory and conclusive.

\subsection{Exploratory research design}

It is also known as qualitative research, it seeks to discover new relationships it aims to define the main problem $\&$ induce the identification of the relevant variables and the possible alternative solutions it can further be divided into three parts.

\subsection{Conclusive research}

It is also known as quantitative research; it is designed to help executives of action that is to make the decision.

\section{Data analysis and interpretation}

1. What is the age group?

\begin{tabular}{|c|c|}
\hline PARTICULARS & NUMBERS \\
\hline COSTLY & $32(20 \%)$ \\
\hline AFFORDABLE & $82(51.3 \%)$ \\
\hline DEPENDS & $46(28.8 \%)$ \\
\hline TOTAL & $\mathbf{1 6 0}(\mathbf{1 0 0} \%)$ \\
\hline
\end{tabular}

\section{Education}

\begin{tabular}{|c|c|}
\hline PARTICULARS & NUMBER \\
\hline UNDERGRADUATE & $16.5 \%$ \\
\hline GRADUATE & $20.3 \%$ \\
\hline POSTGRADUATE & $58.2 \%$ \\
\hline PROFESSIONAL & $5.3 \%$ \\
\hline TOTAL & $100 \%$ \\
\hline
\end{tabular}

\section{Affordability of product}

\begin{tabular}{|c|c|}
\hline PARTICULERS & NUMERS \\
\hline Yes & $104(65 \%)$ \\
\hline No & $6(3.8 \%)$ \\
\hline May be & $50(31.3 \%)$ \\
\hline TOTAL & $\mathbf{1 6 0}(\mathbf{1 0 0 \%})$ \\
\hline
\end{tabular}

4. Occupation

\begin{tabular}{|c|c|}
\hline PARTICULAR & NUMBER \\
\hline STUDENT & $110(68.3 \%)$ \\
\hline SELF EMPLOYED & $2(1.3 \%)$ \\
\hline EMPLOYEE & $30(18.8 \%)$ \\
\hline OTHER & $18(11.3 \%)$ \\
\hline TOTAL & $\mathbf{1 6 0 ( 1 0 0 \% )}$ \\
\hline
\end{tabular}




\section{Preference to online purchase}

\begin{tabular}{|c|c|}
\hline PARTICULARS & NUMBER \\
\hline $15-20$ & $4(2.5 \%)$ \\
\hline $20-25$ & $84(52.5 \%)$ \\
\hline $25-30$ & $62(38.8 \%)$ \\
\hline $30-35$ & $4(2.8 \%)$ \\
\hline 35 above & $6(3.8 \%)$ \\
\hline TOTAL & $\mathbf{1 6 0}$ \\
\hline
\end{tabular}

\section{Preference of electronics}

\begin{tabular}{|c|c|}
\hline PARTICULARS & NUMBER \\
\hline AMAZON.COM & $92(57.5 \%)$ \\
\hline FLIPKART & $56(35 \%)$ \\
\hline SNAPDEAL & $8(5 \%)$ \\
\hline LOCAL STORES & $4(2.5 \%)$ \\
\hline TOTAL & $\mathbf{1 6 0 ( 1 0 0 \% )}$ \\
\hline
\end{tabular}

\section{Conclusion}

Increased web penetration, a hassle-free shopping environment providing to the web shoppers with one click and therefore the product is delivered at home so, that's why a lot of Indians like shopping online. but at the same time, the companies need to reduce the risks associated with consumer incompetence by techniques like making purchase websites easier to navigate, and introducing web stalls, computers, and other aids in stores. The goal isn't to convert all shoppers to online purchasing, but to show them it's a possibility. Additionally to the above, efforts need to be taken to teach web buyers the steps that require to be undertaken while making an online purchase. Moreover, the feedback of an online customer ought to be captured to identify flaws in service delivery. this could be done through online communities and blogs that function advertising and promoting tools and a supply of feedback for enterprises. I found that it's a challenge for E-marketers to convert low-frequency online consumers into regular consumers through successful website design and by addressing concerns about reliable performance. Thus, web retailing raises a lot of problems than the benefits it currently offers. The standard of products offered online and procedures for service delivery are yet to be standardized. Till the same is done, the buyer is at a higher risk of fraud found that it's a challenge for E-marketers to convert low-frequency online consumers into regular consumers through successful website design and by addressing concerns about reliable performance. Thus, web retailing raises a lot of problems than the benefits it currently offers. The standard of products offered online and procedures for service delivery are yet to be standardized. Till the same is done, the buyer is at a higher risk of fraud.

\section{References}

[1] K. Philip, Marketing Management, Eleventh Edition, Pearson Education, Delhi, (2003).

[2] http://www.emeraldinsight.com/doi/full/10.1108/17554191311303367

[3] http://www .amazon.in/b/ref=gw_m_b_corporate/275-9063862-[4].

[4] http://www.flipkart.com/about-us

[5] http://www.snapdeal.com/info/aboutus

[6] http://www.ebay.in/?aff_source=Google_cpc

[7] www.abhinavjournal.com

[8] http://www.studymode.com/essays/attitude-of-indian-consumers-towards-online 647049.html 
This page is empty by intention. 